\title{
ЖУРНАЛІСТСЬКА ДІЯЛЬНІСТЬ У СОЦІАЛЬНИХ МЕРЕЖАХ (ПРОБЛЕМИ ТА ШЛЯХИ ПОДОЛАННЯ)
}

\author{
ПАХННН Микола Леонідович - кандидат наук 3 державного управління, \\ доцент кафедри кримінального права та кримінології факультету № 6 \\ Харківського національного університету внутрішніх справ
}

DOI 10.32782/NP.2021.3.16

У статті розглядається проблема права на свободу слова та свободу журналістсъкої діяльності в мережі Інтернет. Незважаючи на бурхливий розвиток інформаиійних технологій, Украӥна залишається осторонь світових процесів у сбері збирання, зберігання та розповсюдження інбормациї в мережі Інтернет. Чинне законодавство Украӥни до съогодні не містить визначення поняття електронного засобу масової інформащій, не має спеціального нормативно-правового акта, який би визначав його статус, порядок створення, засади діяльності тощо. Запропоновано прийняття відповідного законодавчого акту, який дозволить зрівняти у правах та обов'язках електронні ЗМІ з традиційними.

Ключові слова: засіб масової інформаиій, право на свободу слова, право на інбормацію, електронні ЗМI, відповідальність журналісma.

\section{Вступ}

У XXI ст. журналістика міцно освоїла всесвітню мережу. Майже всі серйозні інформаційні видання в Україні мають онлайнові версії журналів та газет. Будьякі події та новини миттєво з'являються в мережі та розповсюджуються користувачами Інтернет. Якщо донедавна Інтернет міг розглядатися тільки як платформа для особистого спілкування, то нині Інтернетжурналістика стала вагомою складовою інформаційної індустрії в Україні, а ІнтернетЗМІ для українських користувачів - впливовим джерелом інформації.
Відповідно до ст. 92 Конституції України засади утворення і діяльності засобів масової інформації визначаються виключно законами України, проте чинне законодавство України не містить ані визначення поняття засобу масової інформації в мережі Інтернет, ані спеціального нормативно-правового акта, який би визначав їх статус, порядок створення, засади діяльності тощо.

Проблемам, пов'язаним із розвитком і функціонуванням 3МІ в сучасному суспільстві, присвячено низку фундаментальних і прикладних робіт, велику кількість наукових статей 3 юридичних, політичних, соціологічних наук та державного управління. Теорію масової комунікації та іiі засобів у загальному аспекті розробляли такі дослідники, як: Т. Адорно, Р. Барт, 3. Бауман, Д. Белл, Дж. Бенігер, К. Бєляков, В. Брижко, П. Бурдьє, Н. Вінер, Ю. Габермас, М. Горкгаймер, Б. Гунтер, Т. Ван Дейк, Ж. Дельоз, Ж. Дерріда, Дж. Кері, О. Кузнецова, П. Аазарсфельд, Г. Аасвелл, Т. Маєр, Д. Макквейл, Т. Петерсон, Н. Петрова, I. Погорєлова, Т. Приступенко, Т. Роззак, Ф. Сиберт, В. Шрамм, В. Якубенко. Проблематикою кримінально-правового захисту діяльності засобів масової інформації займалися П. П. Андрушко, А. П. Бабій, П. С. Берзін, Я. С. Безпала, Р. В. Вереша, Ю. В. Городецький, І. О. Зінченко, В. М. Кудрявцев, С. Я. Лихова, Г. В. Аазутіна, А. І. Марущак, М. І. Мельник, 
О. В. Красильнікова, Н. В. Кушакова, В. I. Павликівський, А. В. Тарасенко, B. I. Тютюгін та ін.

\section{Завдання}

Проаналізувати чинне законодавство та досвід зарубіжних країн у сфері правового регулювання відносин у сфері масових комунікацій у мережі Інтернет.

\section{Мета}

На підставі аналізу чинного законодавства у сфері регулювання інформаційних відносин запропонувати шляхи подолання проблем із забезпечення права на свободу слова та журналістської діяльності в мережі Інтернет.

\section{Основний текст}

Правова регламентація діяльності журналістів в Україні забезпечується значною кількістю нормативно-правових актів, частина 3 яких напряму пов'язана 3 конкретними видами засобів масової інформації. Так, одним з перших законів, спрямованих на регулювання сфери інформаційних відносин у незалежній Україні, став закон «Про друковані засоби масової інформації (пресу) в Україні» від 16 листопада 1992 року, що в цілому характеризував прагнення громадян України до свободи слова, права на інформацію після десятиліть існування цензури та державного контролю над 3МІ[1]. Цей закон створював правові основи діяльності друкованих засобів масової інформації (преси) в Україні, встановлював державні гарантії їх свободи. Друкованими засобами масової інформації (пресою) визнавалися періодичні і такі, що продовжуються, видання, які виходять під постійною назвою, з періодичністю один і більше номерів (випусків) протягом року на підставі свідоцтва про державну реєстрацію. Таким чином, гарантії, що надавалися цим законом, стосувалися лише редакції друкованого засобу масової інформації та його журналістів.

Пізніше, у 1993 році прийнятий закон України «Про телебачення і радіомовлення», який стосувався порядку розповсюдження аудіовізуальної інформації за допо- могою телебачення та радіо [2]. Цей закон визначав правові, економічні, соціальні, організаційні умови функціонування сфери телевізійного та радіомовлення на території України, спрямовані на реалізацію свободи слова, прав громадян на отримання повної, достовірної та оперативної інформації, на відкрите і вільне обговорення суспільних питань. Слід зазначити, ціла низка положень у зазначених законодавчих актах дублювалася у зв'язку з тим, що права та обов'язки представників масових медіа за своїм змістом є тотожними незалежно від виду засобу масової інформації. Зокрема, заборона цензури (ст. 2 Закону України «Про друковані засоби масової інформації (пресу) в Україні», ст. 6 Закону України «Про телебачення і радіомовлення»), дотримання основних принципів журналістської діяльності (ст. 3 Закону України «Про друковані засоби масової інформації (пресу) в Україні», ст. 2 Закону України «Про телебачення і радіомовлення»), особливості та гарантії журналістської діяльності (ст. 6 Закону України «Про друковані засоби масової інформації (пресу) в Україні», ст. 38 Закону України «Про телебачення і радіомовлення») тощо.

Поряд 3 цим приймається низка законів, що стосуються загальних питань діяльності журналістів незалежно від виду засобу масової інформації. Так, закони України «Про інформацію» [3], «Про доступ до публічної інформації» [4], «Про інформаційні агентства» [5], зміни до адміністративного та кримінального законодавства формували правові межі та підстави відповідальності за порушення порядку одержання, зберігання та розповсюдження інформації як з боку пересічних громадян, так і безпосередньо журналістів.

Так, 2 жовтня 1992 року приймається закон «Про інформацію» який гарантував право кожного на інформацію, що передбачає можливість вільного одержання, використання, поширення, зберігання та захисту інформації, необхідної для реалізації своїх прав, свобод і законних інтересів. У ст. 22 цього закону роз'яснювалися поняття масової інформації та засобів масової інформації. Саме тодішнє уявлення законодавця 


\section{Кримінальне право, кримінальний процес та криміналістика}

про засоби масової інформації як засоби, призначені для публічного поширення друкованої або аудіовізуальної інформації (ст. 22), призвело до появи двох самостійних законів, які врегульовували діяльність трьох найпотужніших засобів масової інформації на той час - преси і телебачення та радіомовлення.

Важливим є той факт, що в законі встановлювалися основні гарантії діяльності засобів масової інформації та журналістів, зокрема, право здійснювати письмові, аудіота відеозаписи із застосуванням необхідних технічних засобів; право безперешкодно відвідувати приміщення суб'єктів владних повноважень; право не розкривати джерело інформації або інформацію, яка дозволяє встановити джерела інформації; право збирати інформацію в районах стихійного лиха, катастроф, у місцях аварій, масових безпорядків. Також встановлювалася заборона на використання інформації для закликів до повалення конституційного ладу, порушення територіальної цілісності України, пропаганди війни, насильства, жорстокості, розпалювання міжетнічної, расової, релігійної ворожнечі, вчинення терористичних актів, посягання на права i свободи людини.

3 часу прийняття цих законів минуло майже три десятиріччя, i, незважаючи на їх важливість та актуальність, сучасна інформаційна сфера потребує подальшого вдосконалення та коригування. 3'явилися нові засоби масової інформації та підходи до їі (інформації) розповсюдження. Поява таких соціальних мереж, як Facebook, YouTube, Instagram, соціальних месенджерів Viber, Telegram та WhatsApp, перехід засобів масової інформації у мережу Інтернет викликали жваві дискусії з приводу місця та ролі учасників таких інформаційних відносин, їх доступу до інформації та відповідальності за iii розповсюдження неправдивого або забороненого змісту. 3 кожним роком прикладів маніпулювання громадською думкою за допомогою зазначених засобів стає все більше. Так, вибори ректора Харківського університету у 2021 році та дискусії претендентів у своїй більшості відбувалися в площині соціальних мереж, у багатьох ви- падках 3 використанням неправдивої або такої, що принижує честь та гідність особи інформації [6]. Це ж стосується і політичних процесів, зокрема загальнодержавних та місцевих виборів [7]. Соціальні мережі значно спростили ведення агітації, зробивши поширення реклами та віртуальних дописів дешевшим, швидшим, більш персоналізованим і часто непомітним для користувача, що відкрило додаткові можливості для маніпулювання громадською думкою. Серйозність проблеми підкреслює те, що восени 2020 року ООН запропонувала термін «інфодемія» на визначення швидкого та масштабного поширення інформації (як точної, так і неправдивої) та закликала ЗМ I та соціальні мережі до співпраці, аби «запобігати поширенню хибних повідомлень i поширювати точну інформацію, засновану на фактах і даних». Огляд найкращих світових практик підтверджує посилення уваги урядів більшості країн світу до врегулювання обігу медіаконтенту в мережі Інтернет. При цьому наявні прямо протилежні погляди з зазначеної проблематики, від тотального контролю до повної свободи діяльності Інтернет платформ. Прихильники регулювання інформаційної діяльності у соціальних мережах вказують на загрозу неконтрольованого розповсюдження неправдивої інформації та дифамації, розголошення конфіденційної інформації користувачів, а також створення нових можливостей прихованого та персоналізованого впливу на Інтернет користувача. Яскравим прикладом такого впливу є президентська виборча компанія у СІІА у 2016 році, у якій приватна англійська компанія Cambridge Analytica, використовуючи технології глибинного аналізу даних (зокрема, даних соцмереж), незаконно займалася збором інформації про користувачів Інтернету i соцмереж, складанням їх психологічних портретів і розробкою персоналізованої реклами. На сьогодні діяльність компанії є предметом кримінальних розслідувань у Великій Британії та США.

3 метою запобігання незаконного використання персональних даних, у тому числі й політичної реклами у соціальних мережах, на території Европейського 
Союзу з 2018 року діє Загальний регламент про захист даних (General Data Protection Regulation, GDPR), прийнятий у 2016 році. Враховуючи можливості соціальних мереж, таких як Facebook, YouTube, Twitter, пошуковик Google та інших, Загальний регламент про захист даних (GDPR) вимагає зберігання та використання персональних даних користувачів лише за їх інформованої згоди, і запит на згоду має бути простим та зрозумілим для користувача. Персональні дані можуть бути використані лише законним та прозорим шляхом, можуть зберігатися лише для попередньо заявленої мети, мають залишатися конфіденційними та можуть зберігатися протягом обмеженого періоду часу, користувачі можуть оскаржити спосіб зберігання та використання їх даних [7].

3 іншого боку, противники регулювання у соціальних мережах вказують на загрозу прав людини 3 свободи слова та самовираження, а також заборону цензури. Класичними прикладами такої діяльності на рівні держави є Російська Федерація, Китайська Народна Республіка, Корейська Народно-Демократична Республіка, а останнім часом i Республіка Білорусь [8]. Зазначені країни 3 різною успішністю намагаються контролювати Інтернетсередовище. Так, 1 листопада 2019 року у Росії набрав чинності закон, який, крім створення можливості на «відключення Інтернету в разі надзвичайної ситуації», також дає владі право на блокування різних сайтів та соціальних мереж. У КНР більшість соціальних мереж, такі як Twitter, Google, Facebook i WhatsApp взагалі заблоковані, а схожі послуги натомість надають китайські провайдери, такі як Weibo, Baidu та WeChat. Китайська кіберполіція також слідкує за платформами наявних соціальних мереж та переглядає повідомлення політичного змісту. Деякі повідомлення (наприклад, ті, що стосуються подій 1989 р. на площі Тянь ань мень) піддаються автоматичній цензурі та видаляються.

На жаль, Україна на сьогодні залишається осторонь більшості процесів, що відбуваються у сфері регулювання інформаційних Інтернет відносин. Звісно, неможливо стверджувати, що вказана діяльність в нашій країні $є$ повністю не врегульованою. I цивільне, і адміністративне, а також спеціальне законодавство встановлює певні правила поводження 3 інформацією, яке стосується у тому числі, роботи в Інтернет середовищі. Стаття 302 Цивільного кодексу України передбачає право кожної особи вільно збирати, зберігати, використовувати і поширювати інформацію. Збирання, зберігання, використання і поширення інформації про особисте життя фізичної особи без її згоди не допускаються. Фізична особа, яка поширює інформацію, зобов'язана переконатися в іiі достовірності. Порушення зазначених вимог тягне за собою цивільну (ст. ст. 23, 276, 277 ЦК України), а в окремих випадках кримінальну відповідальність (ст. 182 КК України) незалежно від способу та місця і засобів її розповсюдження. Кодексом про адміністративні правопорушення передбачено також адміністративну відповідальність за порушення права на інформацію та права на звернення(ст. 212-3 КпАП України). Закон України «Про доступ до публічної інформації» передбачає також можливості дисциплінарної відповідальності за порушення службовими особами права громадян на отримання інформації (ст. 24).

Таким чином, інформаційна діяльність учасників Інтернет середовища не виключена повністю з поля правового регулювання, 3 іншого боку, чинне законодавство не враховує особливості створення, одержання, зберігання та розповсюдження інформації в Інтернет просторі, не покладає додаткових обов'язків на Інтернет-провайдерів, а також у цілому не врегульовує і не захищає Інтернет медіа як окремий різновид журналістської діяльності. Сам термін «електронні 3МІ» у законодавстві зустрічається досить рідко, зокрема у законах України «Про захист суспільної моралі», «Про недержавне пенсійне забезпечення»,нечисленні ж нагадування про можливість діяльності засобів масової інформації в мережі Інтернет знаходимо лише в Законі України «Про інформаційні агентства» та п. 14 Положення про порядок акредитації журналістів і технічних працівників 3МI при Верховній Раді України від 19 травня 2006 р. [9]. Так,- 


\section{Кримінальне право, кримінальний процес та криміналістика}

ст. 29 цього Закону засобами розповсюдження інформаційних агентств називає друковані та екранні видання, радіо, телебачення (кабельне, супутникове, глобальне), електричний та електронний зв'язок (телеграф, телефон, телекс, телефакс), комп'ютерні мережі та інші телекомунікації. Однак зміст, характер та порядок такої діяльності в законі не розкривається. У той же час, і закон «Про друковані засоби масової інформації (пресу) в Україні» (ст. 8), і закон «Про телебачення і радіомовлення» (ст. 21), а також закон «Про інформацію» (ст. 26) та «Про інформаційні агентства» (ст. 12) вимагають обов'язкової реєстрації суб'єкта інформаційної діяльності. Надання відповідних прав та покладання журналістських обов'язків на учасників інформаційних відносин напряму залежить від реєстрації та визнання зазначених суб'єктів як засобу масової інформації. А тому права та обов'язки журналістів в Інтернет середовищі мають тільки ті працівники мас-медіа, що зареєстровані як друковані або телерадіокомпанії чи інформагентства, наприклад щотижнева друкована газета «Дзеркало тижня», сайти новин телекомпаній « $1+1 »$, «ICTV». Однак, більшість онлайн-видань, які працюють у режимі інформаційний агенцій, не визнаються засобами масової інформації 3 двох причин: через відсутність законодавчого регулювання інтернет-видань, а також небажання самих учасників реєструватися у якості 3МІ. У другому випадку власники інтернет-видань відмовляються покладати на себе додаткові обов'язки 3 приводу поширюваної ними інформації. Сьогодні друковані 3МІ ризикують, коли роблять посилання на мережеві матеріали. Адже у випадку, якщо опублікована ними інформація виявиться неправдивою, жодні посилання на Інтернет-видання як на першоджерело інформації не знімуть із газети або телерадіокомпанії відповідальності [10, с. 231].

Враховуючи відсутність у вітчизняному законодавстві будь-яких вказівок на визначення Інтернет-ЗМI, на перший план виступає наукове розуміння цього явища. На думку окремих науковців, під Інтернетвиданням (3MI) можна розуміти будьякий веб-сайт як складову частину мережі
Інтернет (незалежно від того, у якому сегменті Інтернет такий веб-сайт розташований), що належить певній фізичній чи юридичній особі (незалежно від національної чи географічної належності) і призначений для розповсюдження масової інформації, тобто для здійснення масової комунікації [11, с. 22]. Погодитися 3 таким широким визначенням навряд чи можливо. Надання будь-якому веб-сайту статусу засобу масової інформації не тільки надає певних прав учасникам інформаційних відносин, але й покладає як на засіб масової інформації, так й інших суб'єктів відповідні обов'язки та привілеї, зокрема обов'язкова перевірка поширюваної інформації, звільнення від відповідальності за розповсюдження інформації певного виду, доступ до місць природних катастроф та інше. Саме тому повинна залишатися певна відмінність між загальним конституційним правом на інформацію та професійною діяльністю 3 приводу одержання, зберігання та розповсюдження масової інформації.

Зауважимо, що в сусідніх країнах реєстрація інтернет-видань стає нормою. У Білорусі прийняли новий закон «Про засоби масової інформації», який передбачає реєстрацію Інтернет-3МI [12]. Держстандартом Росії введений у дію міждержавний стандарт «Електронні видання. Основні різновиди та вихідні дані», який визначає норми щодо стандарту оформлення видання, мови публікацій, наявності вихідних даних тощо [13]. Федеральним законом РФ «Про внесення змін в окремі законодавчі акти РФ у зв’ язку з удосконаленням правового регулювання у сфері 3МІ» доповнено поняттям мережевого видання [14]. Документ спрямований на модернізацію положень закону «Про засоби масової інформації». Він враховує організаційні, технічні, економічні зміни у сфері виробництва і розповсюдження електронних засобів масової інформації, які відбулися за останні десятиліття, перспективи розвитку ринку телерадіомовлення, пов'язані з переходом до цифрового мовлення. Таким чином, запроваджується можливість зареєструвати Інтернет-видання як засіб масової інформації. Така реєстрація не є обов'язковою, 
але внаслідок реєстрації Інтернет-видання набуває прав і обов'язків 3МІ [10, с. 233].

Неодноразові намагання українського законодавця врегулювати діяльність інтернет-3МІ поки що залишаються нереалізованими в практичній площині. Нагадаємо лише декілька 3 них, зокрема проєктом Закону про Концепцію державної інформаційної політики передбачалося визнання засобами масової інформації електронних ресурсів у мережі Інтернет шляхом добровільної реєстрації. Однак Верховна Рада України 05.07.2011 р. відхилила у другому читанні зазначений проєкт [15]. Також відповідний законопроєкт внесено урядом та зареєстровано у Верховній Раді України за № 6603 від 30 червня 2010 р. Він передбачав введення штрафів для «незареєстрованих інформагентств» та встановлення адміністративної відповідальності за порушення законодавства про інформаційні агентства [16]. Цей законопроєкт Верховна Рада України мала розглянути6 липня 2011 р., однак його було знято 3 розгляду.

Не полишає українська влада також спроби повернути кримінальну відповідальність за наклеп та образу в засобах масової інформації. 16 січня 2014 р. законом України «Про внесення змін до Закону України «Про судоустрій і статус суддів» та процесуальних законів щодо додаткових заходів захисту безпеки громадян» було встановлено кримінальну відповідальність за наклеп (ст. 151-1 КК України); незаконне збирання, зберігання, використання, знищення, поширення конфіденційної інформації про працівника правоохоронного органу, працівника державної виконавчої служби, суддю, їхніх близьких родичів або членів сім'ї (ст. 343 та ст. 376 КК України); несанкціоноване втручання в роботу державних електронних інформаційних ресурсів або інформаційних, телекомунікаційних, інформаційно-телекомунікаційних систем критичних об'єктів національної інформаційної інфраструктури (ст. 361-3 КК України); несанкціоновані збут або розповсюдження інформації з обмеженим доступом, що оброблюється в державних електронних інформаційних ресурсах (ст. 361-4 КК
України); несанкціоновані дії з інформацією, що обробляється в державних електронних інформаційних ресурсах або інформаційних, телекомунікаційних, інформаційно-телекомунікаційних системах критичних об'єктів національної інформаційної інфраструктури (ст. 362-1 КК України) [17]. У подальшому цей закон було повністю скасовано.

\section{Висновки}

На сьогодні онлайн-простір продовжує залишаться поза увагою українського законодавця, як у контексті надання відповідних прав його учасникам, так і встановлення відповідних обов'язків, зокрема відповідальності за дезінформацію, незаконну політичну агітацію. Останне десятиріччя свідчить про перенесення уваги пересічного українця з традиційних 3МІ до альтернативних джерел інформації, перш за все, мережі Інтернет. Враховуючи той факт, що Інтернет-3МІ відрізняється від традиційних 3МІ фактично тільки сферою здійснення діяльності, а також те, що засади утворення і діяльності 3МІ визначаються тільки законами України (ст. 92), необхідність врегулювання діяльності соціальних мереж та Інтернет 3МІ є нагальною вимогою часу.

Віднесення Інтернет видання до засобу масової інформації можливе лише на підставі відповідного закону із обов'язковою реєстрацією та наданням відповідних прав та обов’язків учасникам інформаційних відносин.

Прийняті закони не повинні обмежувати природнє право людини на свободу думки та самовираження, права одержувати, зберігати та розповсюджувати інформацію, у тому числі, у мережі Інтернет.

\section{Лiтература}

1. Закон України «Про друковані засоби масової інформації (пресу) в Україні»№ 2782-XII від 16 листопада 1992 року. URL: https://zakon.rada.gov.ua/laws/show/278212\# Техt (дата звернення 5.07.2021).

2. Закон України «Про телебачення i радіомовлення» № 3759-XII від 21 грудня 1993 року. URL: https://zakon.rada.gov.ua/ 


\section{Кримінальне право, кримінальний процес та криміналістика}

laws/show/3759-12\#Text (дата звернення 5.07.2021).

3. Закон України «Про інформацію» № 2657-XII від 2 жовтня 1992 року. URL: https://zakon.rada.gov.ua/laws/show/265712\# Техt (дата звернення 5.07.2021).

4. Закон України «Про доступ до публічної інформацї». URL:https://zakon.rada.gov. ua/laws/show/2939-17\#Text (дата звернення 5.07.2021).

5. Закон України «Про інформаційні агентства». URL : https://zakon.rada.gov. ua/laws/show/74/95-\%D0\%B2\%D1\%80\#Text (дата звернення 5.07.2021).

6. Бакіров погрожує судом одному 3 кандидатів у ректори ХНУ імені Каразіна. URL: https://2day.kh.ua/ua/kharkow/bakirovpogrozhue-sudom-odnomu-z-kandidativ-urektori-khnu-imeni-karazina (дата звернення 5.07.2021).

7. Регулювати не можна ігнорувати. Як світ контролює дезінформацію в інтернеті. URL: https://www.oporaua.org/article/ vybory/disinformation/22735-reguliuvatine-mozhna-ignoruvati-iak-svit-kontroliuiedezinformatsiiu-v-interneti (дата звернення 5.07.2021).

8. Аукашенко утвердил новации в законы о СМИ и массовых мероприятиях. Что меняется и когда.URL:https://www.belta.by/ president/view/lukashenko-utverdil-novatsiiv-zakony-o-smi-i-massovyh-meroprijatijahchto-menjaetsja-i-kogda-442677-2021/ (дата звернення 5.07.2021).

9. Розпорядження Голови Верховної Ради України «Положення про порядок акредитації журналістів і технічних працівників ЗМІ при Верховній Раді України»від 19 травня 2006 р. № 420. URL: https://zakon.rada.gov.ua/laws/show/420/06\%D1\%80\%D0\%B3\#Text (дата звернення $5.07 .2021)$.

10. Бурило Ю. П. Щодо визначення адміністративно-правового статусу Інтернетвидань та організаційно-правових засад державного управління в сфері їх діяльності // Науковий потенціалсвіту2006: матеріали III міжнар. наук.-практ. конф. (18-29 верес. 2006 р.). Дніпропетровськ: Наука i освіта, 2006. T. 15. С. 20-28.
11. Закон Республики Беларусь «О средствах массовой информации» № 427-3 от 17 июля 2008. URL:https:/pravo.by/document/? guid $=3871 \& \mathrm{p} 0=\mathrm{H} 10800427$ (дата звернення 5.07.2021).

12. ГОСТ 7.83-2001. СИБИД. Әлектронные издания. Основные виды и выходные сведения. URL:http://www. internet-law.ru/intlaw/laws/gost.htm(дата звернення 5.07.2021).

13. Федеральный закон «О внесении изменений в отдельные законодательные акты Российской Федерации в связи с совершенствованием правового регулирования в сфере средств массовой информа-

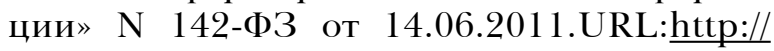
www.consultant.ru/document/cons_doc LAW 115124/ (дата звернення 5.07.2021).

14. Каплій О.В. Інтернет-видання 3МI як новий вид традиційних 3МІ: поняття та сучасний стан конституційно-правового регулювання. Актуальні проблеми держави i права. 2011. Вип. 61. С. 227-235.

15. Проект Закону про Концепцію державної інформаційної політики. URL:http://w 1.c1.rada.gov.ua/pls/zweb2/webp roc4 2?pf3516=7251\&skl=7 (дата звернення 5.07.2021).

16. Проект закона Украины «О внесении изменений в некоторые законодательные акты Украины относительно усовершенствования системы государственной регистрации информационных агентств» № 6603 от 30.06.2010. URL:http://search. ligazakon.ua/l_doc2.nsf/link1/JF53F00A.html (дата звернення 5.07.2021).

17. Закон України «Про внесення змін до Закону України «Про судоустрій і статус суддів» та процесуальних законів щодо додаткових заходів захисту безпеки громадян» від 16.01.2014 № 721-VII // Відомості Верховної Ради України. 2014. № 22. Ciт. 801.

\section{JOURNALISM ACTIVITY IN SOCIAL NETWORKS (PROBLEMS AND WAYS TO OVERCOME)}

The article considers the problem of the right to freedom of speech and freedom of journalistic activity on the Internet. Despite the rapid development of information tech- 
nology Ukraine is involved in the global processes in the collection, storage and dissemination of information on the Internet. The current legislation of Ukraine today does not contain a definition of the concept involved in mass information on the Internet, does not have a special legal act that would determine their status, procedure, principles of activity, etc.

Different approaches to the regulation of electronic media are analyzed. It has been proven that total censorship of electronic media violates the natural right to freedom of speech and information. On the contrary, the refusal of state intervention in the field of information activities on the Internet deprives electronic media of legal protection compared to traditional media. Current Ukrainian legislation does not take into account the specifics of creating, receiving, storing and disseminating information on the Internet, does not impose additional responsibilities on Internet providers, and generally does not regulate and protect Internet media as a separate type of journalistic activity.
In order to avoid illegal activity on the Internet for the collection, receipt, storage and distribution of information recommended to turn to the experience of European countries, including the General Regulation on data protection adopted in 2016.

Given the characteristics of the media, their goals and objectives, it is proposed to separate the grounds for legal regulation of the general human right to information and special professional powers of the media. According to the author of the article, there should be a certain difference between the general constitutional right to information and professional activity regarding the receipt, storage and dissemination of mass information.

The conclusions propose the adoption of a relevant legislative act that will allow to equalize the rights and responsibilities of electronic media with traditional ones.

Key words: mass media, right to freedom of speech, right to information, electronic media, responsibility of a journalist. 